\author{
D.D. Jantassova*, E.A. Zhdanova \\ Karaganda Technical University, Kazakhstan \\ (*Correspondent author e-mail: d.dzhantasova@kstu.kz) \\ Scopus Author ID: 57189027014
}

\title{
Benchmarking as an effective tool in managing the quality of the educational process at a technical university
}

\begin{abstract}
The article deals with the problems and prospects of using benchmarking as a tool for solving quality problems of a technical university educational process. This research is carried out during the implementation of the project «Capacity building for the internationalization of a technical university by means of digital learning technologies» approved by the priority «Scientific foundations» Mangilik el «(education of the XXI century, fundamental and applied research in the humanities)» and funded by the Science Committee of the Ministry of Education and Science of the Republic of Kazakhstan (Grant No. AP08052214). Within the framework of the Project, benchmarking was selected as the main tool for the effective implementation of internationalization at Karaganda Technical University. The author discloses the main content of the «benchmarking» concept, presents the goal, scientific methods and potential of the project, considers the main types, principles and phases of benchmarking. Tyumen Industrial University was chosen as a competing institution, due to the similarity of the higher education systems in post-Soviet countries. When comparing and analyzing the possibilities of benchmarking, the following key aspects were considered: the content of educational courses, the way of students' and teachers' thinking, the use of available resources and quality control of training offered.
\end{abstract}

Keywords: benchmarking, internationalization, higher education, technical university, international experience, educational programs, academic mobility, partner university, quality control of the studying process.

\section{Introduction}

As the processes of economy's globalization and internationalization advance, higher education faced new goals - training of professional personnel who are qualified and able to work effectively in the changed conditions of the global market. The internationalization of education have various goals, including: diversification and growth of financial revenues to attract foreign students for fee paying education, expanding curricula and teaching students of their university in foreign partner universities, improving the quality of education and research by the participation of students and teachers in the international process exchange of knowledge, etc. The development of international interuniversity cooperation makes it possible to organize joint research projects, exchange programs for students and teachers, and special programs for foreign students. These changes, characteristic of the education process itself, are taking place against the background of broader processes of change, covering the economy of individual countries, regions and the world as a whole.

This study is carried out within the framework of the project «Capacity building for the internationalization of a technical university by means of digital learning technologies «, approved by the priority «Scientific foundations» Mangilik el «(education of the XXI century, fundamental and applied research in the humanities)» by grant funding for young scientists at 2020-2022.

The aim of the project is to develop and implement a model for developing the potential of a technical university internationalization via digital learning technologies to implement sustainable and feasible strategies for the educational process internationalization of training technical specialists, taking into account the national and international context. Assessment of the potential needs for internationalization, the development and implementation of measures to build the potential for the educational programs internationalization in technical specialties based on the development of specialized competencies that allow strengthening the qualifications and abilities of students and teachers at the international level.

\section{Materials and research methods}

In the course of this study, at the first stage of analyzing the internationalization process of a technical university, it was decided to use benchmarking methods, which consists in identifying the methods of a suc- 
cessful organization of a company work with the identification of a «implementation tool» that allows the company to achieve high efficiency in the field of production, business processes or use resources.

The internationalization of higher education at the national and institutional level in any country should be understood as a process of integrating the international intercultural or global dimension into the main functions of the education system. Very close to this concept is Knight's definition, who views the internationalization of higher education as the integration of international, intercultural and global aspects in the function of education. Internationalization in higher education includes intercultural and international dimensions that directly affect both research and learning. This includes practices that require the use of new technologies, knowledge, people, values and ideas from different international contexts. (Knight and de Wit 1997). International academic mobility contributes to equally well-developed educational systems and institutions, exacerbating existing inequalities [1].

The internationalization process is supported through accreditation and assessment of the university's performance. Hellmann et al. (20000, Qiang (2003) and Kreber (2009) offer a number of arguments in favor of internationalization, such as attracting foreign students specializing in research or work in the labor market. However, internationalization means cooperation with international universities, transparency and recognition of qualifications in the educational process of students (Barnett et al. 2010) [1]

The most common form of higher education internationalization is academic mobility of students - the departure of a certain number of students to study abroad. Most European countries have had a constant influx of students from their former colonies for many years. A significant proportion of young people from Latin America seek to obtain a degree in universities in the United States and Canada. According to UNESCO, the level of international student mobility has grown by $300 \%$ over the past 25 years. According to experts, by 2010 the number of students studying abroad will be 2.8 million, and by $2025-4.9$ million. Student mobility is stimulated by various state and regional programs. Many countries conclude bilateral and multilateral agreements in this area. The most famous European programs are «Erasmus», and then (since 1995), «Socrates». The Erasmus program (started in 1987 to help create a common market in Europe) and associated mobility schemes such as Comet, Lingua, and others have aimed to create a European model of higher education. Student exchange is seen as a powerful tool for the development of a common European market for specialists and skilled workers.

An equally important element of the internationalization process is the mobility of the teaching staff. Although faculty mobility is not as well researched as the area of student mobility, it can be considered the second most important form of internationalization in higher education. Traditionally, international faculty mobility is driven by research and scientific work, but in a number of regions and in certain areas of education, such as management and business administration, there are special schemes for regional and international training for young researchers and teachers.

Often the processes of student and teaching mobility are so interconnected that it is very difficult to separate them. An example is the mobility programs for undergraduates and doctoral students. Master's and doctoral programs include a period of study, in addition, students of these programs are actively involved in teaching at a bachelor's degree. Therefore, the mobility program for undergraduates and doctoral students includes components of learning, research and teaching.

The internationalization process has been reflected in changes to the content of the curriculum. On the one hand, realizing the need to comply with the complex process of continuous and rapid updating of knowledge, universities are striving to improve their educational programs, to offer the most recent areas of knowledge. On the other hand, traditions are still highly valued in education, and the invariability of some of the attributes of higher education is a definite signal of the high quality of the programs offered.

It is not without reason that many universities strive to trace their history, linking their origins, whenever possible, with the oldest educational institutions. In the service sector, the length of time a service provider has been on the market, its prestige and name have always been the basis of trust in the quality of the services it offers. In the field of educational services, i.e. services related to the transfer of knowledge, these quality criteria are even more valuable [2].

\section{Research findings}

The issues of unification of the requirements for higher education programs are reflected in the socalled «Bologna Process», a broad movement of higher educational institutions of transition to a three-level (bachelor's-master's-doctoral degree) higher education system. Programs with an international theme or strong international component have gained great popularity in many European countries in recent years. 
Moreover, this happens not only in the traditionally open ideas of international cooperation in Holland, but also in France and Germany, countries that are known for a very cautious attitude towards international innovations in their education. However, in both France and Germany, a growing number of programs are taught in English.

It should be noted that with all the support of mobility programs by regional organizations, with all the commitment of universities themselves, the main goal of internationalization is not sending $100 \%$ of students abroad (although it would be foolish to deny the benefits of the experience they acquire), but the availability of internationalization results, which is called «at home» No wonder that one of the special groups of the European Association for International Education (EAIE) is called «Internationalization at Home» (IAH). It is this form of internationalization that makes the results of international interuniversity cooperation available to all students without exception [2].

Within the framework of the Project, benchmarking was selected as the main tool for the effective implementation of this form of internationalization («internationalization at home») at the Karaganda Technical University.

The term «benchmarking» comes from the word «benchmark», which means a mark on a fixed object, for example, a mark on a pole indicating the height above sea level. In the most general sense, a benchmark is something that has a certain quantity, quality and ability to be used as a standard or benchmark when compared with other objects. Benchmarking is a systematic activity aimed at finding, evaluating and learning from the best examples, regardless of their size, business area and geographic location. It is the art of discovering what others are doing better than us, learning, improving and applying their methods of work.

The purpose of benchmarking is to reliably establish the likelihood of an organization's success via research and ensure its revolutionary development. Benchmarking is a new direction for business development. It is about finding and learning the best methods and ways of entrepreneurship to run your own business even better and more productively. Such a procedure is carried out only with the mutual consent of the participating companies and in the presence of reliable information on indicators determined by the companies [3].

Benchmarking is used in various fields of social activity, including the field of educational services. Benchmarking in higher education is an important measuring instrument for improving the education system, making changes in order to embody the concept of «education throughout life», with the aim of providing students with opportunities to successfully master knowledge [4]. The most applicable types of benchmarking in the field of education are:

Internal benchmarking - the study of the activities of the internal departments of an educational institution in order to improve their performance;

Competitive benchmarking is the study of the experience of universities of the same orientation in order to borrow the best practices of partner universities.

Functional Benchmarking - the process of comparing with any university with the best reputation.

Having defined the main content of the concept of «benchmarking», S.A. Lifanova [3] identifies the following basic principles:

- Reciprocity. Benchmarking is an activity based on mutual relations, consent and exchange of data that provides a «win-win» situation for both parties. But reciprocity does not happen blindly. First, it is necessary to agree on the limits of the range of information, the order of data exchange, the logic of the study.

- Analogy. The partners' operational processes should be similar. Any process can be assessed as long as the research team can translate it into the cultural, structural and entrepreneurial context of their enterprise.

- Measurement. Benchmarking is the comparison of performance measured across multiple facilities; the aim is to establish why there are performance differences and how to achieve their best value. intuition.

Credibility. Benchmarking should be based on evidence, accurate analysis and process learning, not just

As a model for the implementation of the goals of the project, a model of effective benchmarking developed by scientists from the Academy of Economic Research (Romania) was chosen. The model includes 5 phases of benchmarking:

- Phase 1 - the phase of planning — the goal is to identify external and internal factors (promoting and inhibiting the development process) in the work that require changes. The instruments of this stage are: regulations, personnel, questionnaires of students and stakeholders, recruitment programs, budget allocation. Analysis of these factors will help identify gaps that need to be addressed. 
- Phase 2 - the phase of analysis. This phase involves the involvement of all participants in the process (involving external organizations) in order to determine the vision of specific goals, concepts, language, culture, obligations, obstacles and opportunities.

- Phase 3 - the phase of projection and correlation, which includes: improvement of methodology and general recommendations in order to implement a quality system in accordance with European quality standards; external and internal assessment of universities; creation of a common database, including criteria, standards and indicators in order to provide information on the status of the development of the program at the university level.

- Phase 4 - the phase of management changes and implementation of solutions. This stage involves the following steps: development of three types of questionnaires (students, teachers, administrative building).

- Phase 5 - the phase of progress monitoring. This stage is based on the need to provide support from the higher education institution in the development and implementation of effective quality assurance systems. The aim of this phase is to introduce annual benchmarking indicators to compare universities at professional and institutional level [5].

In line with the objective of the Project and the analysis of the studied literature, the competitive benchmarking method was chosen as the first stage, that definitely reflects the scientific novelty of the research, since this stage is one of the systematization stages of the theoretical and methodological foundations of benchmarking as a strategic tool for the development of management activities of universities based on the adaptation of best management practices.

We studied the experience of benchmarking at the Tyumen Industrial University, due to the similarity of higher education systems in post-Soviet countries [6].

For a benchmarking exercise, it is important to choose a partner university. Based on the experience of the scientists of Tyumen Industrial University, choosing a partner university, it is necessary to take into account the following parameters: the direction of training specialists, communication with leading enterprises, regional indicators and the number of students in an educational institution; entry of the partner university into the top 200 universities in the world, the number of undergraduates and doctoral students at the university is at least $25 \%$, the number of foreign students is at least $30 \%$, the level of university research is in line with world quality standards, the presence of Nobel laureates among university employees.

When comparing and analyzing the possibilities of benchmarking, the following key aspects were considered: the content of educational courses not provided at the Russian University, the way of thinking of students and teachers, the use of available resources, the teaching staff and control of the learning process.

In the process of analyzing the content of educational courses at the benchmarking university, a number of advantages associated with the degree of informatization of the courses were identified. Thus, in a benchmarking university, there is a high level of students' ability to have access to paid software required for teaching and research the university spends a sufficient amount of material resources on informatization of the learning process [6]. The availability of access to international databases creates an opportunity for students in the benchmarking university to develop interdisciplinary relationships, while students of Tyumen University have access only to the free elibrary.com system, which significantly complicates access to the study of international experience in the field under study.

As for the way of thinking of students and teachers of the two studied universities, here the authors of the article noted the following differences and features. Based on the requirements for an engineer of a modern formation, he must have the following qualities: flexible thinking, high motivation for self-development, the ability to abandon views and beliefs that do not meet modern requirements, knowledge of foreign languages and programming languages, communication and teamwork skills. Benchmarking University spends hundreds of thousands of dollars annually to update software available to students free of charge at any time, which contributes to an increase in student self-employment [7]. Students at a benchmarking university are full-fledged participants in the educational process (take an active part in lectures, discussions, find independent solutions to the questions posed, create their own materials). The authors note that the students of a Russian university have not developed a sufficient skill of independent work, due to the strict adherence to the use of prescribed resources.

In addition, it should be noted that, one of the main benchmarking university tasks is the selection of teaching staff for the efficient organization of the studying process.

The university practices the «invited guest» technology; classes at the university are conducted by specialists from large companies and organizations in order to familiarize students with real working conditions. 
Unlike Russian university, in which lectures and practical classes are conducted by one teacher, in a benchmarking university lectures and practical spells are conducted by different teachers (course coordinator is a lecturer and an assistant who works directly with students). The motto of benchmarking university is not «good» education, but «excellent» education, and feedback is an effective tool here, allowing students to regulate the learning process.

As a fourth aspect, for comparison, the authors identified an indicator of learning process quality control at a benchmarking university. All educational programs of the university are approved by specialized bodies in accordance with the field of training engineers, which allows you to regularly update educational programs in accordance with the requirements of modern production, while at a Russian university all bachelor's and master's programs are approved by the Ministry of Education and Science. In addition to this, differences were noted in the control of students' knowledge, the analysis showed that the content of the examination material at a benchmarking university is double checked and approved (internal check - a lecturer of this university, external check - a lecturer of another university), which significantly improves the quality of the content the examination material, while at a Russian university the content of the examination material is determined directly by the lecturer himself, which reduces the objectivity of assessing students' knowledge.

\section{Conclusion}

The conducted analysis allowed us to define a number of criteria used for benchmarking, which cover almost all areas of the educational process. In order to determine benchmarking as an effective tool to improve the educational activities of the university, the following actions have been identified: increasing the degree of participants' interest in the process of creating a list of criteria taking into account the main trends in educational policy; selection of a system or methodology that collects primary data and determines the level of their reliability; analysis and interpretation of data obtained based on the proposed indicators.

To undertake further comparisons of activities and detect what exactly and how is done to achieve certain values of the identified indicators in the universities participating in the analysis, it is impossible to limit oneself to only one type of benchmarking. If necessary to obtain an accurate picture of the process and choose the right method for describing and documenting it, you must additionally use the process mapping. For instance, to stay focused on the main processes of internationalization, such as attracting foreign students, attracting foreign scientists, concluding international treaties and agreements. We believe that the construction of a process map deserves additional attention of researchers in international relations in higher educational institutions, because this may be the key to uncovering the success or failure of the target institution in comparison with the partner institution.

The measuring of level of internationalization of universities can be addressed by using several types of benchmarking tools such as process mapping, process performance measurement, project management, questionnaire preparation, interviewing, etiquette and legal issues. To cover all the key aspects of university internationalization, using one tool may not be enough. Therefore, within the framework of the research project, there were carried out such procedures as: interviewing, process performance measurements, questioning among administrators of international education, performing a process mapping and studying the experience of internationalization of other universities via literature review.

The experience of benchmarking university internationalization conducted by a research team has shown that the process of internationalization is very difficult to measure and compare due to the lack of accurate benchmarks or indicators. Therefore, to measure the effectiveness of internationalization processes, internationally recognized indicators were used, including the questionnaire that was compiled on the basis of the international action results of universities in the Republic of Kazakhstan.

The scientific novelty of the research results is a detailed-developed action plan for the benchmarking analysis of the internationalization process in a technical university, which includes 5 phases of benchmarking (the phase of planning, the phase of analysis, the phase of projection and correlation, the phase of management changes and implementation of solutions, the phase of progress monitoring, aimed at sustainable capacity building for the internationalization of the educational process) using such tools as performing a mapping process, process performance measurement, interviewing and an internationalization questionnaire, which formed the basis of the strategy for implementing the methodology of benchmarking the internationalization process, taking into account the specifics of the development of higher technical education. 


\title{
References
}

1 Jumakulov Z. Higher Education Internationalization: Insights from Kazakhstan / Z. Jumakulov, A. Ashirbekov // HERJ Hungarian Educational Research Journal. — 2016. - Vol. 6 (1). - 38-58 p.

2 Jantassova D.D. Using MOOCs in teaching ESP / D.D. Jantassova, D.R. Ahmetova // XVIth International Scientific and Practical Conference for Young Researchers «The World of Science Without Borders». — 2019. — 6-13p.

3 Лифанова С.А. Бенчмаркинг в сфере образовательных услуг [Электронный ресурс] / С.А. Лифанова // Journal of Siberian Medical Sciences. - 2008. - № 1. - Режим доступа: https://cyberleninka.ru/article/n/benchmarking-v-sfere-obrazovatelnyhuslug (дата обращения: 20.10.2020).

4 Jantassova D. Environmental tendencies in engineering education / D. Jantassova, G. Smirnova, V. Gotting // Proceedings of 2015 International Conference on Interactive Collaborative Learning, ICL 2015. - 679-688 p.

5 Cătălina C. Internationalization in higher education / Cătălina Crișan-Mitra, \& Anca Borza // International Conference «Risk in Contemporary Economy», XVIth Edition, 2015. - 144-151 p.

6 Kurushina V.A. Technologies of polytechnic education in global benchmark higher education institutions / V.A. Kurushina, E.V. Kurushina, M.Ju. Zemenkova // IOP Conference Series Materials Science and Engineering. — Vol 357. — 2018. — 1-7 p.

7 Krishnamoorthy, Bala \& D'Lima, Benchmarking as a measure of competitiveness / Krishnamoorthy, Bala \& D'Lima, Christine // Int. J. of Process Management and Benchmarking. - 4, 2014. — 342 - 359 p. 10.1504/IJPMB.2014.063240.

8 Anca G.I. Sustainable success in higher education by sharing the best practices as a result of benchmarking process / Anca Gabriella Ilie, Mihaela Maftei and Oana Antonia Colibasanu // Amfiteatru Economic 13, Special. — No. 5. — 2011. — 688-697 p.

\author{
Д.Д. Джантасова, Э.А. Жданова
}

\section{Бенчмаркинг техникалық университеттің оку үрдісінің сапасын басқарудың тиімді құралы ретінде}

\begin{abstract}
Мақалада эталондық бақылауды техникалық университеттің оқу үрдісінің сапалық мәселелерін шешудің құралы ретінде пайдаланудың мәселелері мен болашағы талқыланған. Бұл зерттеу «Мәңгілік Ел» ғылыми негіздері (XXI ғасыр білімі, гуманитарлық ғылымдардағы іргелі және қолданбалы зерттеулер)» басымдықпен бекітілген «Сандық оқыту технологиялары арқылы техникалық университеттің интернационалдандыру әлеуетін дамыту» жобасын іске асыру барысында жүзеге асырылды. 2020-2022 жылдарға арналған жоба аясында эталондық бағалау Қарағанды техникалық университетінде интернационалдандыруды тиімді жүзеге асырудың негізгі құралы ретінде таңдалды. Авторлар «эталондық бақылау» тұжырымдамасының негізгі мазмұнын ашып, жобаның мақсаты, ғылыми әдістері мен әлеуетін ұсынған, негізгі түрлерін, салыстыру принциптері мен кезеңдерін қарастырған. Жобаның мақсатына сәйкес зерттеу үшін конкурстық эталондық әдіс таңдалды. Бұрынғы кеңестік елдердегі жоғары білім беру жүйелерінің ұқсастығына байланысты, Тюмень индустриалды университеті таңдалды. Бенчмаркингтің мүмкіндіктерін салыстыру және талдау кезінде келесі негізгі аспектілер қарастырылды: білім беру курстарының мазмұны, студенттер мен оқытушылардың ойлау тәсілі, қолда бар ресурстарды пайдалану және оқу процесін бақылау.
\end{abstract}

Кілт сөздер: эталондық бағалау, интернационалдандыру, жоғары білім, техникалық университет, халықаралық тәжірибе, білім беру бағдарламалары, академиялық ұтқырлық, серіктес университет, білім беру үрдісінің сапасын бақылау.

\section{Д.Д. Джантасова, Э.А. Жданова}

\section{Бенчмаркинг как эффективный инструмент в управлении качеством образовательного процесса технического университета}

В статье рассмотрены проблемы и перспективы использования бенчмаркинга как инструмента решения проблем качества образовательного процесса технического университета. Настоящее исследование осуществлено в ходе реализации проекта «Развитие потенциала интернационализации технического вуза посредством цифровых технологий обучения», утверждённого по приоритету «Научные основы «Мәңгілік Ел» (образование XXI века, фундаментальные и прикладные исследования в области гуманитарных наук)» по грантовому финансированию для молодых ученых на 2020-2022 гг. В рамках Проекта бенчмаркинг был выбран в качестве основного инструмента с целью эффективного внедрения интернационализации в Карагандинском техническом университете. Авторами раскрыто основное содержание понятия «бенчмаркинг», представлены цель, научные методы и потенциал Проекта, рассмотрены основные виды, принципы и фазы бенчмаркинга. В соответствии с целью Проекта за основу исследования был выбран метод конкурентного бенчмаркинга. В качестве вуза-конкурента выбран Тюменский индустриальный университет, по причине сходства систем высшего образования постсоветских стран. При сравнении и анализе возможностей бенчмаркинга были рассмотрены сле- 
дующие ключевые аспекты: содержание образовательных курсов, образ мышления студентов и преподавателей, использование доступных ресурсов и контроль процесса обучения.

Ключевые слова: бенчмаркинг, интернационализация, высшее образование, технический университет, международный опыт, образовательные программы, академическая мобильность, университетпартнер, контроль качества учебного процесса.

\section{References}

1 Jumakulov, Z., \& Ashirbekov, A. (2016). Higher Education Internationalization: Insights from Kazakhstan. Hungarian Journal of Educational Research, 6(1), 38-58. Retrieved from https://doi.org/DOI:10.14413/HERJ.2016.01.03

2 Jantassova, D.D., \& Ahmetova, D.R. (2019). Using MOOCs in teaching ESP. XVIth International Scientific and Practical Conference for Young Researchers «The World of Science Without Borders», 6-13.

3 Lifanova, S.A. (2008). Benchmarkinh v sfere obrazovatelnykh usluh [benchmarking in the field of educational services]. Journal of Siberian Medical Sciences, No. 1. Retrieved from https://cyberleninka.ru/article/n/benchmarking-v-sfere-obrazovatelnyhuslug [in Russian].

4 Jantassova, D., Smirnova, G., \& Gotting, V. (2015). Environmental Tendencies in Engineering Education. Proceedings of 2015 International Conference Interactive Collaborative Learning, ICL, 679-688. Retrieved from https://link.springer.com /chapter/10.1007/978-3-030-11935-5_16

5 Cătălina Crișan-Mitra, \& Anca Borza. (2015). Internationalization in higher education. International Conference "Risk in Contemporary Economy», XVIth Edition, 144-151.

6 Kurushina, V.A., Kurushina, E.V., \& Zemenkova, M.Ju. (2018). Technologies of polytechnic education in global benchmark higher education institutions. IOP Conference Series Materials Science and Engineering, Vol. 357, 1-7.

7 Krishnamoorthy, Bala \& D'Lima, Christine. (2014). Benchmarking as a measure of competitiveness. Int. J. of Process Management and Benchmarking, 4, 342-359. 10.1504/IJPMB.2014.063240.

8 Anca Gabriella Ilie, Mihaela Maftei and Oana Antonia Colibasanu (2011). Sustainable success in higher education by sharing the best practices as a result of benchmarking process. Amfiteatru Economic 13, Special No. 5, 688-697. 